\title{
Christoffer Green-Pedersen
}

\section{Det Radikale Venstres betydning i dansk politik. Er den så stor, som vi går og tror?!}

\begin{abstract}
Det hævdes ofte, at Det Radikale Venstre har afgørende betydning i dansk politik. Partiets betydning er imidlertid mere begrænset. Det Radikale Venstre har aldrig for alvor været i stand til at tilvejebringe et brud med blokpolitikken i Danmark i form af for eksempel brede regeringer. Dette skyldes, at når først Det Radikale Venstre har valgt side, så har det ikke den store magt over oppositionen. For oppositionen vil den rationelle oppositionsstrategi med henblik på at vinde regeringsmagten som regel være en stemmemaksimerende strategi, hvor man kun vil indgå forlig på områder, der ikke er centrale i oppositionspolitikken. Det historiske ifolketingsvalget i november 2001 er således, at oppositionen for første gang i 30 år havde held med at danne et flertal uden om Det Radikale Venstre, men der er intet nyt i, at den har forsøgt.
\end{abstract}

Det må betegnes som barnelærdom i dansk politik, at midterpartierne ${ }^{2}$ og især Det Radikale Venstre spiller en helt central rolle. Mange vil sikkert mene, at når det kommer til stykket, betyder det ikke så meget, om det er Socialdemokratiet eller de borgerlige partier, der sidder på regeringsmagten. Det er alligevel Det Radikale Venstre, der har det afgørende ord. De to blokke i dansk politik bliver nødt til at rette sig ind efter partiet, fordi det nu engang er den måde, man kommer til magten på. Kort sagt kan man sige, at partiet har haft en betydning, der ligger væsentligt ud over, hvad dets mandattal umiddelbart berettiger det til.

Forskningen i dansk politik har langt hen ad vejen støttet denne opfattelse af Det Radikale Venstres centrale betydning i dansk politik. En række studier af regeringsdannelser i Danmark (Kaarsted, 1988; Elklit, 1999; Miller, 1996; Skjæveland, 2003) har for eksempel alle fremhævet Det Radikale Venstres helt centrale rolle. Studier af udvalgte policyområder som udviklingspolitik (Olsen, 1995) fremhæver også partiets betydning, og da Damgaard og Svensson (1989) rejste spørgsmålet om "who governs" i Danmark, var svaret mere Det Radikale Venstre end den siddende regering. I forlængelse af understregningen af Det Radikale Venstres betydning kan man se folketingsvalget og regeringsskiftet i november 2001 som historiske. Bortset fra SV-regeringen var det første gang siden 1971, at Danmark fik en regering uden mere eller mindre direkte støtte fra Det Radikale Venstre, og man kan se det som en væsentlig drejning i retning af blokpolitik.

Denne artikel har til formål at præcisere Det Radikale Venstres betydning eller magt i dansk politik. Som Dahl (1986) har påpeget, er spørgsmålet om aktørers magt ikke et enten-eller-spørgsmål. Man bliver for eksempel nødt til at undersøge "omfang" og "domæne" af aktørers magt, dvs. på hvilke områder og over hvilke andre aktører en given aktør har magt. Det er en sådan klarlægning af Det Radikale Venstres magt og betydning, som vil blive fors $\emptyset \mathrm{gt}$ i det følgende.

At påstå, at Det Radikale Venstre ikke har haft en central rolle i dansk politik, også ud over hvad partiet ud fra en ren numerisk betragtning har været berettiget 
til, ville være forkert. For eksempel er det uomtvisteligt, at regeringsskiftene i 1982 og 1993 fandt sted, fordi Det Radikale Venstre skiftede side i dansk politik. Artiklen hævder imidlertid, at Det Radikale Venstres magt reelt er mere begrænset.

De fleste studier, der fremhæver Det Radikale Venstres betydning i dansk politik, er således også studier, der med udgangspunkt i koalitionsdannelsesteorier har studeret regeringsdannelser. Konklusionen i denne artikel fremkommer imidlertid ved i stedet at vurdere Det Radikale Venstres betydning ud fra den teoretiske litteratur om midterpartier. Ved at inddrage denne litteratur bliver det muligt at vurdere Det Radikale Venstres rolle i et komparativt lys, hvilket gør det nemmere at identificere begrænsningerne i partiets magt. I forlængelse heraf vil den empiriske del af artiklen være en vurdering af Det Radikale Venstre betydning for partikonkurrencen omkring økonomisk politik i Danmark de seneste 20 år. Dette område er valgt, fordi der er tale om det mest centrale politikområde de seneste 20 år.

Artiklen er opbygget på følgende måde: Det første afsnit giver en kort beskrivelse af forskellige studier af dansk politik og deres vurdering af Det Radikale Venstres betydning. Fokus vil være på studier af regeringsdannelser, og i den forbindelse vil koalitionsdannelseslitteratur også blive diskuteret kort, da den typisk danner udgangspunkt for studier af regeringsdannelser. Det næste afsnit præsenterer den teoretiske litteratur om midterpartier. Dernæst følger den empiriske analyse, der følges op af en samlet vurdering af Det Radikale Venstres rolle i dansk politik. Ud over at sammenfatte artiklen indeholder konklusionen en diskussion af CD og Kristeligt Folkepartis betydning set $\mathrm{i}$ lyset af analysen af Det Radikale Venstre.

Studier i dansk politik og deres vurdering af Det Radikale Venstres betydning Studier, der direkte har fors $\emptyset \mathrm{gt}$ at vurdere Det Radikale Venstres rolle i dansk politik, er der faktisk ingen af. Til gengæld er der masser af studier af forskellige aspekter af dansk politik, der fremhæver Det Radikale Venstres centrale rolle. Studier af regeringsdannelser i Danmark er et af de klareste eksempler. Millers (1996: 240) studie af danske regeringer fra 1901 til 1995 konkluderer, at hvis Det Radikale Venstre støtter Socialdemokratiet, kommer der socialdemokratiske regeringer, og hvis partiet støtter de borgerlige, får Danmark borgerlige regeringer. Det Radikale Venstre er med andre ord omdrejningspunktet i forhold til regeringsdannelser i Danmark. Denne konklusion er helt på linje med Kaarsteds (1988 og 1992) historiske studier af danske regeringsdannelser og Elklits (1999) unders $\varnothing-$ gelse af regeringsdannelserne i 1973, 1975, 1982 og 1988.

Det teoretisk mest ambitiøse studie af danske regeringsdannelser er Skjæveland (2003). Dette studie tager udgangspunkt i den omfattende internationale litteratur om regeringsdannelser (se for eksempel Laver, 1998; Martin og Stevenson, 2001). I denne litteratur er der god støtte til at fremhæve Det Radikale Venstres betydning i dansk politik. Skjæveland (2003: 27-30) henviser således til Laver og Schofields (1990) "medianteori" om den magt, det parti har, der kontrollerer medianmandatet i parlamentet. Partiet vil ifølge Laver og Schofield diktere politikken og kan reelt tage på ferie på Bermuda og stadig bestemme, fordi der ikke kan dannes et flertal enten til højre eller venstre for det. Laver og Schofield henviser (1990: 110-113) 
selv til Det Radikale Venstre som et eksempel, og Skjæveland (2003) viser, hvorledes teorien i en mere sofistikeret udgave kan forklare danske regeringsdannelser: Medianpartiet, som oftest Det Radikale Venstre, afgør, hvilken af de to blokke der får regeringsmagten og gør det på baggrund af en vurdering af, hvilken af blokkene der ligger tættest på partiet med hensyn til policy. ${ }^{3}$ Alt $i$ alt er studier af danske regeringsdannelser enige om, at Det Radikale Venstre har overordentlig stor indflydelse i dansk politik. Vil man have regeringsmagten i Danmark, må man holde sig gode venner med Det Radikale Venstre.

Det Radikale Venstres store indflydelse i dansk politik understreges også af en række andre studier. Kigger man for eksempel på dansk udviklingspolitik, som er en radikal mærkesag, kan man hurtigt få fornemmelsen af, at Det Radikale Venstre dikterer dansk politik. Mens mange andre lande har indskrænket deres udviklingsbistand i de seneste 20 år, har Danmark i kraft af initiativer fra Det Radikale Venstre $\emptyset$ get sin bistand væsentligt (Olsen, 1995). ${ }^{4}$ Den nye VK-regering har imidlertid gennemført besparelser på området, hvilket blot understreger Det Radikale Venstres afgørende betydning for væksten i udgifterne til området frem til folketingsvalget i 2001.

Et yderligere eksempel er Damgaard og Svenssons (1989) unders $\varnothing$ gelse af koalitionsdannelser i Folketinget i midten af 1980'erne. Det alternative flertal betød, at Det Radikale Venstre hyppigere end regeringen var med i de flertal, der vedtog lovgivning i Folketinget. Partiet havde for så vidt større magt i dansk politik end regeringen. Systemet med alternative flertal var unikt for 1980'ernes borgerlige regeringer, men at det overhovedet kunne etableres kan tages som en klar indikation af Det Radikale Venstres store betydning i dansk politik. Endelig fremhæver brede fremstillinger af det danske partisystem som Pedersen (1987: 9-10) også Det Radikale Venstres særlige rolle.

Alt i alt synes forskellige vinkler på dansk politik at pege i samme retning. Det Radikale Venstre har været den centrale aktør i dansk politik, og ved at kunne vælge, hvem der skulle have regeringsmagten, har partiet i praksis i høj grad bestemt over dansk politik. Som sagt er formålet med denne artikel ikke at hævde, at de studier, der blev citeret ovenfor, er forkerte. Det er svært at bestride, at Det Radikale Venstre har spillet en central rolle i forbindelse med de fleste af de regeringer, der rent faktisk er blevet dannet i Danmark i efterkrigstiden, og at partiet har været afgørende for dansk udviklingspolitik. Pointen er imidlertid, at hvis man ser Det Radikale Venstre i lyset af den teoretiske litteratur om midterpartier, der vil blive præsenteret nedenfor, opdager man en række begrænsninger af partiets magt. Kort sagt er argumentet, at selv om Det Radikale Venstre ofte er medianparti, så betyder det ikke, at partiet dikterer dansk politik, som Laver og Schofield (1990) ellers lægger op til. Dette skyldes især, at Det Radikale Venstres magt over oppositionen i Danmark er begrænset.

\section{Midterpartier i teoretisk perspektiv}

Midterpartier var længe et noget overset emne inden for statskundskaben (Daalder, 1984). Det hang blandt andet sammen med, at en række klassikere inden for forskningen i partier og partisystemer havde et negativt syn på midterpartier. Duverger 
(1965: 215) hævdede således, at "centret ikke er andet end en kunstig gruppering af venstrefløjens højrefløj og højrefløjens venstrefløj" (forfatterens oversættelse). Partierne er en unaturlig afvigelse fra det naturlige topartisystem. Sartori (1976) så eksistensen af stærke midterpartier som et træk ved polariseret pluralisme og som medvirkende til centrifugal konkurrence i partisystemer.

I løbet af 1990'eme er der imidlertid blevet publiceret en række studier, der giver en noget anden vurdering af midterpartier. For det første er Duvergers argument om, at midterpartier er en unaturlig konstruktion uden sin egen politiske position, blevet kritiseret. Både Keman (1994 og 1997) og van Kersbergen (1997) argumenterer således for, at midterpartier, hos van Kersbergen særligt kristeligt demokratiske partier, er en distinkt gruppe af partier, som ikke blot kan reduceres til venstreorienterede $h \varnothing j$ refløjspartier eller højreorienterede venstrefløjspartier. Hazan (1997: 160-166) argumenterer i sit studie af midterpartier i særligt Holland og Danmark også imod Duvergers påstand om, at centret er en kunstig konswruktion. Samtidig modificerer han Sartoris påstand om, at eksistensen af midterpartier fører til centrifugal partikonkurrence. Det er rigtigt, at der vil være en tendens til, at de store partier på hver side af midterpartiet vil bevæge sig mod fløjene for at presse centeret til at vælge side, men midterpartier vil være modstandstandsdygtige og vil svare igen ved at kæmpe for en "centerdoktrin", dvs. en villighed til at samarbejde med begge politiske sider, et $\emptyset$ nske om at holde ekstremistiske partier uden for indflydelse, et ønske om samarbejde hen over midten og en generel vægt på samarbejde og kompromisvillighed.

Endelig har den nyere litteratur om midterpartier også søgt at differentiere midterpartier efter deres politiske betydning. Centralt er her Kemans (1994) begreb om kardinalpartier (pivot parties på engelsk). Det betegner midterpartier, der både har en central og dominerende placering i partisystemet. Hermed menes, at det er store partier i vælgermæssig forstand med en central placering, der betyder, at de vil være afgørende $\mathrm{i}$ forbindelse med regeringsdannelser og lovgivningsprocesser. Hverken for partierne til højre eller til venstre for kardinalpartier er det realistisk at opnå et flertal uden kardinalpartiet. Politisk vil det derfor være næsten umuligt at danne regering uden om kardinalpartier, der som hovedregel vil være regeringsparti og oftehave statsministerposten. De empiriske eksempler, som Keman identificerer, er de kristeligt demokratiske partier i Holland, Belgien og Italien, det finske centerparti, Fianna Fail i Irland og det liberale FDP i Schweiz. Det er vigtigt at være opmærksom på, at Kemans begreb om kardinalpartier afviger fra den tankegang om kardinalpartier (pivotal parties på engelsk), der findes i litteraturen om regeringsdannelser. I denne sidstnævnte litteratur menes der partier, der fungerer som tungen på vægtskålen, som Det Radikale Venstre. Keman identificerer imidlertid ikke Det Radikale Venstre som kardinalparti, og det er klart hvorfor, hvis man elaborerer lidt videre på hans analyse (Green-Pedersen, 2003).

Det afgørende træk ved kardinalpartier er som beskrevet ovenfor, at de er i en situation, hvor det er urealistisk at danne regering uden om dem. For partieme til højre og venstre for kardinalpartiet er der derfor som regel kun én måde at komme i regering på, nemlig at bevæge sig mod midten og samarbejde med kardinalpartiet. Partieme til højre og venstre kan tit opleve, at de kunne hente flere stemmer ved at 
bevæge sig mod fløjen, men de kan ikke få regeringsmagten på den måde, og centripetal konkurrence kommer til at dominere partisystemet. Kardinalpartier vil med andre ord være i stand til at gennemtvinge en centerdoktrin og forhindre blokpolitik. Ironisk nok kan den centrale magt, som kardinalpartier har, ramme dem som en boomerang. I både Holland og Finland har man set, at det er lykkedes for kardinalpartierne at trække de andre store partier så langt ind mod midten, at de kan regere uden kardinalpartiet. Således har man i begge lande i 1990'erne haft brede regeringer, regnbuekoalitionen i Finland og "lilla" regeringer i Holland. ${ }^{5}$ Kardinalpartiernes magt har været så stor, at de nærmest har gjort de andre store partier til midterpartier. Centerdoktrinen lever så videre uden kardinalpartiet (GreenPedersen, under udgivelse).

Denne gennemgang er vigtig i forhold til diskussionen om Det Radikale Venstres magt $0 \mathrm{~g}$ betydning, fordi den viser, hvor betydningsfulde nogle midterpartier faktisk kan være og har været. Når de er stærke nok, kan de forhindre blokpolitik og igangsætte en slags "implosion" af partisystemet, hvor alle de store partier reelt bliver midterpartier, og konkurrencen i partisystemet bliver stærkt centripetal. Den afgørende faktor, for om et parti kan fungere som kardinalparti i den forstand, det blev beskrevet ovenfor, er, om det er realistisk at danne regering uden om partiet ud over brede regeringer. Beskrivelsen af kardinalpartier som centrale og dominerende $\mathrm{i}$ forbindelse med lovgivning og regeringsdannelser synes umiddelbart at passe fint på Det Radikale Venstre, men Kemans empiriske analyser udpeger som sagt ikke partiet som et kardinalparti, og i den følgende empiriske analyse af dansk politik efter 1982 med særlig henblik på økonomisk politik vil det blive søgt vist, at partiet ikke har haft den magt, som centerpartier i for eksempel Holland og Finland har haft. I Danmark er det nemlig en fornuftig oppositionsstrategi at forsøge at danne regering uden om Det Radikale Venstre.

\section{Dansk økonomisk politik efter 1982.}

\section{Hvordan kan man genvinde regeringsmagten?'}

I september 1982 gik Anker Jørgensen af og overlod regeringsmagten til Poul Schlüter. Dette regeringsskift skyldtes ikke mindst, at Det Radikale Venstre havde tabt tilliden til Socialdemokratiets evne til at redde landet ud af det økonomiske uføre (Elklit, 1999: 77-79). Schlüter lancerede hurtigt en genopretningsplan, som med støtte fra Det Radikale Venstre og Fremskridtspartiet blev gennemført nogenlunde, som regeringen havde tænkt sig det (Green-Pedersen, 2002). Firkløverregeringen faldt imidlertid i forbindelse med finansloven for 1984. Fremskridtspartiet stemte af princip imod finansloven, og så kunne Socialdemokratiet vælte regeringen (Christiansen, 1994). Det efterfølgende valg styrkede dog regeringen, idet den nu kunne regere uden støtte fra Fremskridtspartiet. Den kunne dermed fortsætte genopretningspolitikken, hvilket den gjorde, om end der kom en del slinger i valsen op mod folketingsvalget i 1987 (Nannestad og Green-Pedersen, under udgivelse).

I relation til Det Radikale Venstres magt og indflydelse er det centralt at undersøge Socialdemokratiets oppositionspolitik. Hvis Det Radikale Venstre skulle kunne betegnes som kardinalparti i den forstand, der blev skitseret ovenfor, skulle Socialdemokratiet, i hvert fald i løbet af perioden, bevæge sig i retning af Det Radikale 
Venstres position, dvs. acceptere genopretningspolitikken og vise kompromisvillighed over for regeringen. Det skulle være deres eneste chance for igen at komme i regering. Socialdemokraternes oppositionspolitik var imidlertid alt andet end forsonlig og kompromisvillig. Man angreb alle dele af regeringens genopretningsprogram på nær realrentebeskatningen. Sammen med fagbevægelsen arrangerede partiet også store demonstrationer, og man anklagede regeringen for at skabe sociale massegrave (Green-Pedersen, 2002: kap. 7).

Spørgsmålet er så, hvordan denne oppositionspolitik kan forklares. Socialdemokratiet havde nok frivilligt afgivet regeringsmagten, men efterhånden som den borgerlige regering overlevede de 100 dage, som LO havde spået den, bredte desperationen for at genvinde regeringsmagten sig. Forklaringen på Socialdemokratiets uforsonlige oppositionspolitik skal derfor findes i de strategiske muligheder for at genvinde regeringsmagten (Green-Pedersen og van Kersbergen, 2002). Set i lyset af, at Det Radikale Venstre havde bundet sig tæt til den borgerlige regering, var der intet, der tydede på, at partiet ville være villig til at pege på en socialdemokratisk regering foreløbig, snarere tværtimod. En strategi med at forsøge at genvinde regeringsmagten ved at tækkes Det Radikale Venstre var med andre ord en meget langsigtet strategi, og Socialdemokratiet havde ikke lyst til at vente meget længe på at komme i regering igen. Den strategi, partiet valgte, var i stedet at forsøge at vinde et flertal med SF. Dette blev især tydeligt op til valget i 1987, hvor partiet for første gang inden et valg talte om at regere enten sammen med eller på basis af SF, og meningsmålinger antydede, at det ikke var utopisk, at et sådant flertal kunne etableres (Bille, 1992: 8).

Denne politiske situation ændrede sig ikke væsentligt før efter valget i 1990. Valget i 1987, der igen gjorde regeringen afhængig af Fremskridtspartiet, gav Socialdemokratiet et vist håb om, at borgerlig uenighed kunne bringe det til magten, som det havde været tilfældet i 1970'erne, men efter dannelsen af KVR-regeringen i 1988 var det klart, at det havde lange udsigter. Valget i 1990 ændrede dog situationen. Efter at have forladt KVR-regeringen fjernede Det Radikale Venstre sig fra VK-regeringen, og det samme gjorde CD og Kristeligt Folkeparti. Især CD søgte aktivt at placere sig mere centralt i midten af dansk politik (Green-Pedersen, 2002: kap. 7). For første gang under Poul Schlüters regeringstid blev en mere midtsøgende kurs en tiltrækkende strategi for Socialdemokratiet med henblik på at genvinde regeringsmagten, og det fik blandt andet partiet til at støtte finanslovene for 1992 og 1993 (Christiansen, 1994). Efter Tamilsagen var det så også midterpartierne, der bragte Socialdemokratiet til magten igen.?

Perioden med borgerlige regeringer illustrerer meget godt, hvorfor det ikke er rimeligt at betegne Det Radikale Venstre som et "kardinalparti". For Socialdemokratiet var et flertal med SF, selv om det ikke lykkedes, et realistisk alternativ til en midts $\varnothing$ gende kurs, hvor man ventede på, at Det Radikale Venstre skulle blive træt af de borgerlige partier. Konsekvensen blev, at dansk politik blev domineret af blokpolitik og centrifugal konkurrence. Det Radikale Venstre, og mod slutningen af perioden også $C D$, fors $\emptyset$ gte at gennemtvinge en centerdoktrin, dvs. samarbejde hen over midten, udelukkelse af Fremskridtspartiet og en bred regering. Succesen med denne doktrin var imidlertid begrænset. Forligene mellem regeringen og So- 
cialdemokratiet var få, en bred regering blev aldrig seriøst forhandlet, og i forbindelse med Finansloven for 1990 måtte Det Radikale Venstre acceptere et forlig med Fremskridtspartiet for ikke at give Socialdemokratiet vetoret over forhandlingerne.

For de borgerlige partier var situationen efter dannelsen af den første Nyrupregering i 1993 meget parallel til den situation, som Socialdemokratiet befandt sig i i 1982. Spørgsmålet var, om man via en midtsøgende kurs skulle fors $\emptyset$ ge at genvinde midterpartiemes gunst, eller skulle man fors $\emptyset$ ge at erobre et flertal med Fremskridtspartiet? I lyset af, at alle tre midterpartier deltog i Nyrup-regeringen, havde den første strategi kun et langsigtet perspektiv, og ikke overraskende satsede de borgerlige partier på at vinde et flertal med Fremskridtspartiet ved valget i 1994 . De stemte således imod både den første Nyrup-regerings skatte- og arbejdsmarkedsreform, selv om indholdet lå tæt op ad de ideer, som den sidste Schluiter-regering havde haft. Set i lyset af meningsmålingeme var strategien ikke utopisk, men som bekendt lykkedes det ikke for de borgerlige at genvinde regeringsmagten ved valget i 1994. Perioden fra 1994 til 1998 forløb for så vidt på den samme måde. VK gjorde ikke noget synderligt for at tækkes Det Radikale Venstre. ${ }^{8}$ Valget i 1998 gav heller ikke de borgerlige regeringsmagten, selv om det var tæt på. Strategien for at genvinde regeringsmagten ændrede sig dog ikke, idet man satsede på et ikke-socialistisk flertal uden om Det Radikale Venstre, hvilket også syntes den eneste farbare vej. Det Radikale Vènstre kan ikke gå fra at deltage i en regering med Socialdemokratiet og til at støtte en borgerlig regering, og derfor var der ingen grund til at tækkes partiet. Som bekendt gav VK-strategien så endelig resultat ved valget i november 2001 .

Perioden fra 1993 til 2001 var altså også domineret af blokpolitik. Det Radikale Venstre havde efterhånden helt opgivet centerdoktrinen og havde ikke problemer med at inddrage Enhedslisten meget i for eksempel finanslovsforhandlinger og som støtteparti for Pinsepakken i 1998. CD var i perioden det parti, der klarest fremførte en centerdoktrin. Partiet gik således ind i Nyrup-regeringen i 1993 for at holde SF uden for indflydelse, hvilket imidlertid ikke lykkedes og var en væsentlig grund til partiets udtræden af regeringen i 1996.

\section{Det Radikale Venstres muligheder og begrænsninger}

Analysen af dansk partipolitik med vægt på økonomisk politik siden 1982 viser de begrænsninger, der er i Det Radikale Venstres magt. Partiet har ikke haft den rolle, som kardinalpartier har haft i andre partisystemer. Den helt afgørende begrænsning i partiets magt har været det faktum, at det i Danmark har været en reel mulighed at danne regering uden partiets støtte. Ser man på de regeringer, der rent faktisk er blevet dannet i Danmark i perioden, har Det Radikale Venstre spillet en central rolle i de fleste tilfælde, men det gør ikke partiet til et kardinalparti i den forstand, der blev skitseret ovenfor. For Socialdemokratiet under Schlüter-regeringeme var det op til 1990-valget en rationel strategi for at tilbageerobre regeringsmagten at forsøge at vinde et flertal med SF. At det ikke lykkedes, er en anden sag. Det samme gælder den borgerlige opposition under Nyrup-regeringeme, men her lykkedes strategien til sidst. 
Formuleret i magtteoretiske termer (jf. Dahl, 1986) kan omfang og domæne af Det Radikale Venstres magt nu præciseres. Med hensyn til omfang så har Det Radikale Venstre som regel stor indflydelse på, hvilken regering der dannes i Danmark. Med hensyn til domæne og specielt angående centrale områder som økonomisk politik er partiets magt derimod mere begrænset, mens partiet har haft stor indflydelse på mindre politikområder såsom bistandspolitik. Det er også værd at hæfte sig ved, at flygtninge-indvandrerpolitikken, som er blevet et meget centralt område i dansk politik de senere år, bestemt heller ikke har bevæget sig i den retning, Det Radikale Venstre ønsker sig.

Den begrænsning i omfanget af Det Radikale Venstres magt hænger snævert sammen med begrænsninger i domænet, dvs. hvilke aktører man har magt over. Kort sagt kan man sige, at når først Det Radikale Venstre har valgt side i dansk politik, så mister det også sin magt over oppositionen. Den ved godt, som Socialdemokratiet efter 1982 og de borgerlige efter 1993, at så skifter Det Radikale Venstre ikke umiddelbart side igen. Sagt på en anden måde har oppositionen i Danmark ikke de stærke incitamenter til at være midtersøgende, som den har i systemer med kardinalpartier, hvor en midtersøgende strategi er den eneste måde at komme i regering på. ${ }^{9}$ Oppositionen i Danmark har ikke noget incitament til grundlæggende at bryde med blokpolitikken, og heri ligger den centrale forskel til partisystemer med kardinalpartier.

Argumentationen i denne artikel er ikke en modsigelse af koalitionsdannelsesteorier og deres påpegning af Det Radikale Venstres betydning i forbindelse med regeringsdannelser. Argumentationen sætter dog spørgsmålstegn ved Laver og Schofields påstand om, at et midterparti kan tage på ferie på Bermuda og "diktere" politikken, fordi det bestemmer, hvem der får regeringsmagten. I Danmark betyder oppositionens holdning meget for, hvilket indhold politikken får, og som sagt er Det Radikale Venstres magt over oppositionen mere begrænset. Som eksempel kan nævnes, at den socialdemokratiske oppositionspolitik under Schlüter-regeringeme gjorde det umuligt for regeringen at reformere arbejdsløshedsdagpengesystemet, også selv om regeringen måske godt kunne have skaffet et borgerligt flertal for en sådan reform (Green-Pedersen, 2002: kap. 7).

Argumentation i denne artikel betyder dog ikke, at oppositionen i Danmark ikke er villig til at indgå forlig med regeringen. Det vil den gerne, så længe det ikke betyder, at den må opgive vigtige politiske våben i oppositionspolitikken. Socialdemokratiet ville i 1980'erne for eksempel gerne indgå forlig med de borgerlige regeringer om realrentebeskatning og nedsættelse af rentefradraget, fordi det ikke var emner, som ville være centrale i politiske angreb på Schlüter-regeringerne. For de borgerlige partier fra 1993 til 2001 var situationen den omvendte. Man havde

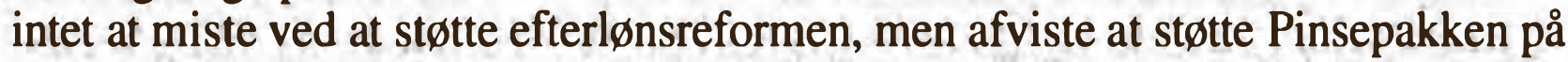
grund af den skattereform, den indeholdt. Skattepolitik var som bekendt et af de centrale borgerlige angrebsvåben mod Nyrup-regeringerne (if. Green-Pedersen, 2001). I forlængelse heraf må man også forvente, at Socialdemokratiet kun vil være villig til at samarbejde med den nuværende regering, hvis det drejer sig om emner, hvor partiet ikke vil få det store ud af at angribe regeringen. Derimod må man forvente, at partiet vil være helt uvilligt til at støtte for eksempel nedskærin- 
ger af velfærdsstaten, da det vil være en kærkommen lejlighed til at angribe regeringen.

Lidt mere teoretisk er det også vigtigt, at implikationen ikke er, at dansk politik ikke kan være midterorienteret. I sin klassiske analyse viste Downs (1957), hvorledes konkurrencen i et topartisystem, hvis vælgerholdningerne er fordelt på en bestemt måde, vil medføre centripetal konkurrence. Et bloksystem, som er en rimelig tilnærmelse af det danske partisystem, kan analyseres parallelt med et topartisystem, og implikationen er, at begge blokke vil trække mod midten, hvis det er en rationel måde at vinde stemmer og dermed regeringsmagten på. Et oplagt eksempel på en sådan dynamik er Venstres kurs over for velfærdsstaten i valgkampen i november 2001. Denne strategi kunne umiddelbart ligne en tilnærmelse til Det Radikale Venstre, men det var den bestemt ikke. Som Dahl (1986) påpeger, er det vigtigt ikke at tage det, at en aktør gør, som en anden geme vil have, som udtryk for, at den ene aktør har magt over den anden. Adfærden kan lige så godt, som i Venstres tilfælde, skyldes, at aktøren af egen drift ønsker at gøre noget.

Hvis man graver et spadestik dybere og stiller spørgsmålet, hvad det er, Det Radikale Venstre mangler for at være et kardinalparti, så synes størrelse at være den afgørende faktor. Den store begrænsning for Det Radikale Venstre er, at det ikke er utopisk at vinde regeringsmagten uden partiets støtte. Kardinalpartier har derimod en størrelse, som bevirker, at den eneste mandatmæssige mulighed for at samle et flertal uden dem er brede regeringer. I forlængelse heraf spiller det også en central rolle, at Det Radikale Venstre ikke kan skifte side i dansk politik fra valg til valg. Som Skjæveland (2003) argumenterer for, synes Det Radikale Venstres sideskift i Danmark at være en forholdsvis langsommelig proces, og man kan ikke forestille sig, at partiet før et valg sidder i regering med den ene side for så efter næste valg at støtte den anden side. Implikationen af dette er, at det faktisk er forholdsvis begrænsede perioder, hvor det vil være af interesse for oppositionen at fors $\varnothing g e$ at "lokke" Det Radikale Venstre over på deres side. Perioden fra 1990 til 1993 var en sådan. Spørgsmålet er så, hvor denne begrænsning på Det Radikale Venstres fleksibilitet kommer fra. Kunne partiet ikke blot køre den linje, at det efter hvert folketingsvalg bestemmer sig for, hvilken side i dansk politik det vil støtte? Det var den strategi, som de kristeligt-demokratiske partier i Holland forfulgte, og som lagde maksimalt pres på de andre partier for at tilpasse sig deres position (jf. Green-Pedersen, 2002: kap. 6).

Størrelse synes også her at spille en central rolle. Når Det Radikale Venstre ikke springer fra side til side, skyldes det sandsynligvis dels frygt for, at partiet vil blive angrebet voldsomt af de andre partier for ikke at melde klart ud, hvilken regering man støtter ved at stemme på Det Radikale Venstre, dels frygt for, at vælgeme vil straffe partiet for en sådan adfærd. Mandatfordelingen i det danske Folketing lægger op til blokpolitik, og der er en forventning hos vælgeme om, at Det Radikale Venstre - og de andre midterpartier - vælger side. I forlængelse heraf kan man også overveje, hvorfor vi ikke i nyere tid har haft radikale mindretalsregeringer. En sådan regering ville kunne skifte side fra sag til sag og ville have meget fine man $\varnothing$ vremuligheder. Skjæveland (2003) forklarer det med, at Det Radikale Venstre mangler "office capacity". Man er simpelthen for få til både at besætte ministerposterne 
og have en velfungerende folketingsgruppe. Endvidere er det spørgsmålet, om ikke en sådan regering, ligesom en radikal afvisning af at vælge side før efter et valg, vil blive angrebet voldsomt på sin legitimitet. Det ville være svært at afvise, at en sådan regering qua sit mandattal havde en meget svag forankring i befolkningen, og på den baggrund synes det ikke så overraskende, at Det Radikale Venstre ikke i nyere tid for alvor synes at have forsøgt en sådan løsning.

\section{Konklusion}

At påstå, at Det Radikale Venstre ikke har haft stor betydning i dansk politik, ville være forkert. Den centrale rolle ved de fleste regeringsskift giver partiet stor indflydelse, som kan benyttes til at forfølge partiets mærkesager. Desuden giver deltagelse i regeringer selvsagt også indflydelse. Formålet med denne artikel har imidlertid været at diskutere og kortlægge de begrænsninger, som der er i Det Radikale Venstres magt.

Dette er gjort med udgangspunkt i litteraturen om midterpartier og særligt Kemans (1994) begreb om kardinalpartier. Det Radikale Venstre kan ikke betegnes som et kardinalparti, og heri ligger nøglen til forståelsen af begrænsningerne på dets betydning. I modsætning til kardinalpartier har Det Radikale Venstre aldrig kunnet gennemtvinge en centerdoktrin i Hazans (1997) forstand. Det er kun i begrænset omfang lykkedes at holde fløjpartierne uden for indflydelse, og brede regeringer hen over midten er det, bortset fra den lidet succesfulde SV-regering fra 1978-1979, aldrig blevet til. Forklaringen skal i første omgang findes i den mulighed for at vinde regeringsmagten uden om Det Radikale Venstre, der eksisterer i Danmark, og som blev realiseret efter valget i november 2001, og tidligere er blevet realiseret af Socialdemokratiet og SF fra 1966 til 1968 og 1971 til 1973. Eksistensen af denne mulighed, sammenholdt med Det Radikale Venstres manglende fleksibilitet, bevirker, at den rationelle oppositionsstrategi i Danmark som regel vil være at fors $\emptyset g e$ at vinde et flertal uden om Det Radikale Venstre. Problemet for Det Radikale Venstre er sagt på en lidt anden måde, at domænet for dets magt normalt ikke strækker sig til oppositionen. Den dybereliggende årsag hertil skal søges i partiers begrænsede vælgertilslutning. Det er den, der muligg $ø$ r flertalsdannelser uden om partiet, og som også gør det umuligt for partiet at danne regering alene.

Analysen i det foregående har primært fokuseret på Det Radikale Venstre. Som nævnt findes der yderligere to midterpartier i Danmark, der også i nogle tilfælde har spillet - eller søgt at spille - den samme rolle som Det Radikale Venstre, nemlig CD og Kristeligt Folkeparti. I forlængelse af det foregående må deres magt betegnes som væsentligt mindre end Det Radikale Venstres. Som Skjæveland (2003) argumenterer for, kan man beskrive disse to partier som ufleksible midterpartier, fordi de i praksis kun kan pege på en borgerlig regering, hvilket begrænser deres afpresningspotentiale over for Venstre og Konservative. En sådan erkendelse har sikkert været medvirkende til, at de to partier, og særligt CD, først i 1990'eme søgte at placere sig mere fleksibelt, hvilket kulminerede i deltagelsen i Nyrups første regering. Problemet for de to partier var imidlertid, at deres vælgere straffede dem hårdt. Kristeligt Folkeparti røg ud af Folketinget, og $\mathrm{CD}$ måtte forlade 
regeringen i 1996 for ikke at lide samme skæbne. Siden da har de to partier holdt sig til den borgerlige side, hvilket som bekendt ikke var nok for CD til at sikre deres forbliven i Folketinget.

Sammenfattende kan man sige, at Det Radikale Venstres betydning er stor, også større end partiet er berettiget til ud fra en ren numerisk betragtning, men samtidig er den underlagt nogle klare begrænsninger. Partiet har haft stor indflydelse på, hvilken blok der har regeringsmagten i Danmark, men tilvejebringe et brud med blokpolitikken, som for eksempel kunne danne grundlag for en bred regering, kan partiet ikke. Set ud fra en policy-vinkel kan partiet godt have stor indflydelse på et mindre område som udviklingspolitik, men på de store og politisk afgørende områder er partiets indflydelse mere begrænset. I lyset af denne argumentation fremtræder valget i november 2001 også langt mindre historisk, end hvis man lægger vægt på midterpartiernes rolle. Det historiske ved valget $\mathrm{i}$ november 2001 var, at det lykkedes for Venstre og Konservative at erobre regeringsmagten uden Det Radikale Venstre, men taktikken, som afspejler, at det danske partisystem fungerer som om et bloksystem, er ikke ny.

\section{Noter}

1. En tidligere udgave af denne artikel er blevet præsenteret for forskningsfællesskabet i dansk politik ved Institut for Statskundskab, Aarhus Universitet. Tak til deltagerne og Politicas to anonyme bedømmere for mange nyttige kommentarer og særligt til Asbjørn Skjæveland for mange gode diskussioner om Det Radikale Venstres betydning i dansk politik.

2. Brugen af betegnelserne midter- og centerpartier kan være forskellig. I forlængelse af Hazan (1997: 20-28) kan man bruge betegnelsen midterparti om et parti, der er placeret midt i mellem to politiske blokke. Betegnelsen midterparti er med andre ord relativ til et bestemt partisystem. Et centerparti er derimod et parti, der ligger midt på en absolut defineret højre-venstre-skala. Klassificeringen af et parti som centerparti er altså uafhængig af det partisystem, partiet indgår $\mathrm{i}$, og et centerparti kan godt være det mest højre- eller venstreorienterede parti i et partisystem. De tre relevante partier $i$ en dansk sammenhæng er imidlertid både center- og midterpartier,og forskellen er derfor af mindre betydning for problematikkeni denne artikel. Betegnelsen midterparti vil derfor primært blive brugt i det følgende, da den er mest brugt på dansk.

3. Socialdemolratiet har i perioder også været medianparti, og i det tilfælde forudsiger Skjævelands model (2003), at partiet selv vil danne regering.

4. Dette eksempel har ført til et forslag om at hæve spærregrænsen til fem procent for at undgå en situation, hvor et midterparti udnytter sin position til at få gennemført særstandpunkter (Svendsen, 2001).

5. Den "lilla" regering i Holland måtte afgive magten i sommeren 2002. Den finske regnbuekoalition tabte magten ved valget $\mathrm{i} 2003$.

6. Empiriske analyser af dynamikkerne i et partisystem kan være vanskelige, da det er svært at finde enkle indikatorer på partiernes strategiske adfærd. Det følgende benytter en række indikatorer såsom partiernes villighed til at indgå aftaler, deres valgkampstrategier, udtalelser, partiprogrammer etc. Hvor intet andet fremgår, trækker det følgende på Green-Pedersen (2002).

7. Det er efterhånden kommet ret tydeligt frem, at Det Radikale Venstre og især Niels Helveg Petersen spillede en central rolle i forbindelse med det socialdemokratiske formandsopgør $\mathrm{i}$ 1992. Det kan ses som en indikation på partiets betydning, men i forhold til denne artikels argumentation er det værd at bemærke, at dette skete på et tidspunkt, hvor Det Radikale Venstre netop var i gang med et skifte mod venstre. Samtidig var der også internt i Socialdemokratiet en vis utilfredshed med Svend Auken, blandt andet efter fyringen af Ritt Bjerregaard som politisk 
ordfører, så i væsentlige dele af Socialdemokratiet var der lydhørhed over for det radikale ønske om formandsskifte (jf. Kristiansen og Larsen, 1996; Heltberg, 1996).

8. Op til valget i 1998 foretrak CD, der i mellemtiden var trådt ud af regeringen, på ny en borgerlig regering, ligesom i øvrigt Kristeligt Folkeparti gjorde, der var røget ud ved valget $\mathrm{i} 1994$. Denne udvikling afspejler imidlertid ikke så meget, at V og K tilpassede sig CD og Kristeligt Folkeparti, men at de to partier var nødt til at støtte $\mathrm{V}$ og K igen for ikke at blive yderligere straffet af vælgerne, jf. nedenfor.

9. Dette ses, hvis man sammenligner Socialdemokratiet i Holland og Danmark efter 1982, hvor centrum-højre-regeringer i begge lande lancerede en ny økonomisk politik indeholdende blandt andet offentlige besparelser. Mens Socialdemokratiet i Danmark som sagt var fuldstændigt afvisende, accepterede de i Holland efterhånden besparelserne, fordi de måtte tilnænne sig de Kristelige Demokrater for igen at kunne komme i regering (Green-Pedersen og van Kersbergen, 2002).

\section{Litteratur}

Bille, Lars (1992). ”Den parlamentariske udvikling 1987-1990”, pp. 7-22 i Lars Bille, Hans Jørgen Nielsen og Steen Sauerberg, De uregerlige valgere - valgkamp, medier og valgere ved folketingsvalget 1990, København: Columbus.

Christiansen, Søren L. (1994). "Holdninger til Finansloven", Politica, 26. årgang, nr. 1, pp. 32-45.

Daalder, Hans (1984). "In Search of the Center of European Party Systems", American Political Science Review, Vol. 78, No. 1, pp. 92-109.

Dahl, Robert A. (1986). "Power as the Control of Behaviour", pp. 37-58 in Steven Lukes (ed.), Power, London: Basil Blackwell.

Damgaard, Erik and Palle Svensson (1989). "Who Governs? Parties and Policies in Denmark". European Joumal of Political Research, Vol. 17, No. 6, pp. 731-745.

Downs, Anthony (1957). An Economic Theory of Democracy, New York: Harper and Row.

Duverger, Maurice (1965). Political Parties: Their Organization and Activity in the Modern State, London: Methuen.

Elklit, Jørgen (1999). "Party Behaviour and the Formation of Minority Coalition Governments: Danish Experiences from the 1970s and 1980s", pp. 63-88 in Wolfgang C. Müller and Kaare Strøm (eds.), Policy, Office, and Votes, Cambridge: Cambridge University Press.

Green-Pedersen, Christoffer (2001). "Minority Governments and Party Politics: The Political and Institutional Background to the 'Danish Miracle"', Journal of Public Policy, Vol. 21, No. 1, pp. 63-80.

Green-Pedersen, Christoffer (2002). The Politics of Justification. Party Competition and WelfareState Retrenchment in Denmark and the Netherlands from 1982 to 1998, Amsterdam: Amsterdam University Press.

Green-Pedersen, Christoffer (under udgivelse). "Center Parties, Party Competition, and the Implosion of Party Systems. A Study of Centripetal Tendencies in Multiparty Systems", Political Studies.

Green-Pedersen, Christoffer and Kees van Kersbergen (2002). "The Politics of the 'Third Way'. The Transformation of Social Democracy in Denmark and the Netherlands", Party Politics, Vol. 8, No. 5, pp. 507-524.

Hazan, Reuven Y. (1997). Centre Parties. Polarization and Competition in European Parliamentary Democracies, London: Pinter.

Heltberg, Bettina (1996). Hvor der handles, København: Gyldendal.

Keman, Hans (1994). "The Search for the Centre: Pivot Parties in West European Party Systems", West European Politics, Vol. 17, No. 4, pp. 124-148.

Keman, Hans (1997). "Centre-Space Politics: Party Behaviour in Multi-Party Systems", pp. 85-112 in Hans Keman (ed.), The Politics of Problem-Solving in Postwar Democracies, London: Macmillan. 
Kristiansen, Michael og Thomas Larsen (1996). Niels Helveg Petersen. Manden og magten, K $\varnothing-$ benhavn: Børsen.

Kaarsted, Tage (1988). Regeringen, vi aldrig fik. Regeringsdannelsen 1975 og dens baggrund, Odense: Odense Universitetsforlag.

Kaarsted, Tage (1992). De danske ministerier 1953-1972, København: PFA Pension.

Laver, Michael (1998). "Models of Government Formation", Annual Review of Political Science, Vol. 1, pp. 1-25.

Laver, Michael and Norman Schofield (1990). Multiparty Government, Oxford: Oxford University Press.

Martin, Lanny W. and Randolph T. Stevenson (2001). "Government Fornnation in Parliamentary Democracies", American Joumal of Political Science, Vol. 45, No. 1, pp. 33-50.

Miller, Kenneth E. (1996). Friends and Rivals. Coalition Politics in Denmark 1901-1995, Lanham: University Press of America.

Nannestad, Peter and Christoffer Green-Pedersen (under udgivelse)."Keep the Bumblebee Flying: Economic Policy in the Welfare State of Denmark, 1973-1999" in Erik Albæk et al. (eds.), Managing the Danish Welfare State under Pressure: Towards a Theory of the Dilemmas of the Welfare State, Arhus: Aarhus University Press.

Olsen, Gorm R. (1995). "Dansk Udviklingspolitik. Kompromisets Kunst”, Politica, 27. årgang, nr. 2, pp. 195-212.

Pedersen, Mogens N. (1987). "The Danish 'Working Multiparty System': Breakdown or Adaptation", pp. 1-60 in Hans Daalder (ed.), Party Systems in Denmark, Austria, Switzerland, the Netherlands, and Belgium, London: Frances Pinter.

Sartori, Giovanni (1976). Parties and Party Systems, Cambridge: Cambridge University Press.

Skjæveland, Asbjørn (2003). Government Formation in Denmark 1953-1998, Århus: Forlaget Politica.

Svendsen, Gert T. (2001). "Hæv spærregrænsen til fem procent", kronik i Morgenavisen JyllandsPosten, 17.4.

van Kersbergen, Kees (1997). "Between Collectivism and Individualism. The Politics of the Centre", pp. 113-140 in Hans Keman (ed.), The Politics of Problem Solving in Post-War Democracies, London: Macmillan. 